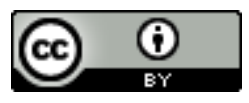

PÄÄKIRJOITUS

\title{
Taneli Hiltunen
}

\section{Eksymisiä, epäonnistumisia ja umpikujia pitkällä 1800- luvulla}

Viimeisin 1800-luvun tutkimuksen verkoston vuosikonferenssi pidettiin Helsingissä Suomalaisen Kirjallisuuden Seuran tiloissa 30.-31.1.2020 kattoteemalla "Eksymisiä, epäonnistumisia ja umpikujia". Ennen ja nyt-numeron 4/2020 kolme refereeartikkelia ovat perinteiseen tapaan syntyneet konferenssiesitelmien pohjalta. Niitä yhdistävät ihmisten välisen vuorovaikutuksen tavat, yhteisöllisyys ja myös sen rakoileminen.

Karolina Kouvola valottaa artikkelissaan sitä, miten tietäjähahmot esitetään 1800-luvun lopulla ja 1900-luvun alussa ruotsinkieliseltä Pohjanmaalta kerätyssä uskomustarina-aineistossa. Kouvolan käyttämistä lähteistä rakentuu kuva, joka ei ole mustavalkoinen, vaan ambivalentti: Tietäjien uskottiin niin parantavan sairauksia, löytävän kadonneita esineitä, ihmisiä ja eläimiä kuin harjoittavan vahingoittavaa noituuttakin. Väärintekemisen ja parantamisen välillä vallitsi uskomuksissa dualiteetti, sillä vaikka tietäjä saattoi tehdä syntiä myymällä sielunsa Paholaiselle, hänellä oli taitoja, jotka hyödyttivät koko yhteisöä säätelemällä sen jännitteitä. Tätä kiehtovaa uskomusperinnettä on tutkittu vain vähän, joten Kouvola esittää, että vernakulaareja uskomusmalleja voidaan hyödyntää myös muiden ruotsinkielisten alueiden perinteen tutkimuksessa.

Miira Vuoksenranta puolestaan käsittelee naisten välistä ystävyyttä siihen liittyvien konfliktien näkökulmasta. Vanhemmassa tutkimuksessa aihepiiri saatettiin idealisoida verrattain ongelmattomaksi, mutta kuten Vuoksenranta osoittaa, riitely ei ollut vierasta 1800-luvun Suomen sivistyneistölle. Artikkelin esimerkkitapauksena Vuoksenranta analysoi kolmen Tammisaaren opettajaseminaarista valmistuneen, kansakouluopettajana työskennelleen ystävättären kirjeenvaihtoa 1870-luvulla. Minna Forss o.s. Rancken (1848-1931), Maria Candolin o.s. Johansson (1849-1935) ja Alma Husberg (1850-1905) ystävystyivät opettajaseminaarissa, mutta valmistumisen jälkeen viranhoito eri puolilla Suomea toi siteiden säilyttämiseen omat haasteensa ja ongelmansa. Vaikka kirjeenvaihto mahdollisti kuulumisten ja ajatustenvaihdon maantieteellisestä etäisyydestä huolimatta, kirjallisessa muodossa tapahtunut kommunikaatio altisti ystävysten välit väärinkäsityksille. Jo katkokset kirjeiden saapumisessa saivat aikaan tunteiden kuohumista, mikä pahimmillaan johti pettymyksiin, kun seminaarivuosien muokkaama maailmankuva ei vastannutkaan kaikilta osin vallitsevaa todellisuutta. Samalla käy selville, miten löystyvän etäystävyyden erimielisyyksiä yritettiin neuvotella.

Anna Kuisminin aiheena ovat ns. maallisten arkkiveisujen laatiminen, myynti ja kulutus Suomessa 1870-luvulta 1900-luvun alkupuolelle. Ne liittyvät laajempaan ilmiöön, jossa puhutun ja kuullun varaan 
rakentuneen kansankulttuurin rinnalle nousi suullis-kirjallinen kulttuuri. Toisin kuin aiemmin, käsiteltynä ajanjaksona arkkiveisuja tehtailivat tavalliset kansanihmiset. Kuismin valottaa kulttuurihistorian kannalta sitä, keitä arkkiveisujen laatijat olivat ja miten heihin suhtauduttiin, ja syventää käsitystä lehtisten myymisestä, ostamisesta ja käyttämisestä. Tämän kaiken hahmottamisessa oma arvonsa on niin sanoma- ja aikakauslehtikirjoituksilla, fiktiivisillä teksteillä kuin muistelmillakin.

Toivotan antoisia lukuhetkiä pitkän 1800-luvun ilmiöiden parissa!

Hämeenlinnassa 13.1.2021

Vieraileva päätoimittaja Taneli Hiltunen 